NOTE

\title{
Chytridiomycosis in frogs from Uruguay
}

\author{
Claudio Borteiro ${ }^{1, *}$, Juan Carlos Cruz $^{2}$, Francisco Kolenc ${ }^{3}$, Andrea Aramburu ${ }^{4}$ \\ ${ }^{1}$ Río de Janeiro 4058, CP 12800, Montevideo, Uruguay \\ ${ }^{2}$ Departamento de Patología, Facultad de Veterinaria, Lasplaces 1550, Montevideo, Uruguay \\ ${ }^{3}$ Universidad Católica del Uruguay, Dr. Javier Barrios Amorín 1578, Montevideo, Uruguay \\ ${ }^{4}$ Calle 43 y Calle O, Parque del Plata, Canelones, Uruguay
}

\begin{abstract}
Amphibian chytridiomycosis caused by Batrachochytrium dendrobatidis is reported in Uruguayan native amphibians for the first time. Histological evidence of infection was observed in tadpoles of Hypsiboas pulchellus, Odontophrynus maisuma, Physalaemus henselii, and Scinax squalirostris. The effects of chytridiomycosis on these species are still unknown. However, the disease is of potential concern for the conservation of the apparently declining species $P$. henselii and also for $O$. maisuma, given its restricted distribution in habitats which are being increasingly disturbed.
\end{abstract}

KEY WORDS: Batrachochytrium dendrobatidis - Amphibian disease - Amphibian conservation · Uruguay Resale or republication not permitted without written consent of the publisher

\section{INTRODUCTION}

Many amphibian species have disappeared or are severely threatened because of multiple factors such as habitat loss, pollution, introduction of non-native species, climate change and infectious diseases (Stuart et al. 2004, Pounds et al. 2006). Studies that focused on pathogens as a cause of amphibian declines greatly increased after the discovery of amphibian chytridiomycosis, a fungal skin disease caused by the chytrid fungus Batrachochytrium dendrobatidis (see Daszak et al. 2007). Chytridiomycosis can be highly pathogenic to amphibian non-larval stages and is linked with mass mortalities and population declines (Berger et al. 1998, Daszak et al. 1999, 2003). The involvement of chytridiomycosis in the decline and extinction of Neotropical amphibians was first documented in Central America and northern South America, where it strongly impacted several amphibian communities (Berger et al. 1998, Lips et al. 2003, 2006). In recent years, B. dendrobatidis has been reported to be widespread farther south, principally along the Atlantic coast of South
America, where disease-linked declines are suspected (Barrionuevo \& Mangione 2006, Carnaval et al. 2006, Toledo et al. 2006). Chytridiomycosis is likely to occur in Uruguayan native amphibians because climatic conditions are highly suitable for the pathogen to be established in the region (Ron 2005). Furthermore, the disease has already been reported from this country in farmed North American bullfrogs Lithobates catesbeianus (Mazzoni et al. 2003).

The amphibian chytrid is associated with keratinized tissues, thus detection is made on samples of adult amphibian skin and oral epithelium surrounding keratinized mouthparts of tadpoles (Berger et al. 1999). Infection at the larval life stage essentially consists of variable amounts of keratin loss that may be non-lethal (Knapp \& Morgan 2006, Symonds et al. 2007). When examining tadpoles of amphibians from northern Uruguay, we noticed the presence of chytrid-like deformities in the oral structures of tadpoles of the leiuperid frog Physalaemus henselii. This finding prompted us to screen for amphibian chytridiomycosis in this and other Uruguayan native amphibians. 
Herein, we report new cases of the disease in this country, expanding its geographic and host range.

\section{MATERIALS AND METHODS}

Twenty-seven tadpoles collected in Uruguay between 2001 and 2007 that exhibited deformities in keratinized oral structures under a stereoscopic microscope were screened for the presence of Batrachochytrium dendrobatidis. Vouchers were deposited in the Batrachians Collection of the Vertebrate Zoology Department (ZVCB), Faculty of Sciences, Montevideo, Uruguay. Specimen details are listed in Table 1. Tadpoles were fixed in situ with formalin $10 \%$. The cephalic region of each specimen was dissected and routinely processed for histological examination; they were embedded in paraffin, sectioned at 4 to $5 \mu \mathrm{m}$ and stained with hematoxylin and eosin. Diagnosis followed the work of Berger et al. (1999).

\section{RESULTS}

We detected chytrid on 18 out of 31 tadpoles: all screened specimens of Hypsiboas pulchellus $(\mathrm{n}=6)$, Odontophrynus maisuma (4), Scinax squalirostris (3) and those of Physalaemus henselii from Pueblo Madera (5). Most relevant oral deformities of tadpoles were partial or total loss of keratinization of jaw sheaths, with erosion of their cutting edge and absence of serrations, and also stunted and missing teeth. The loss of labial teeth was sometimes so extensive that it resulted in wide gaps within tooth rows, or even the lack of entire tooth rows, especially anterior ones. Infected tadpoles were not emaciated, their general

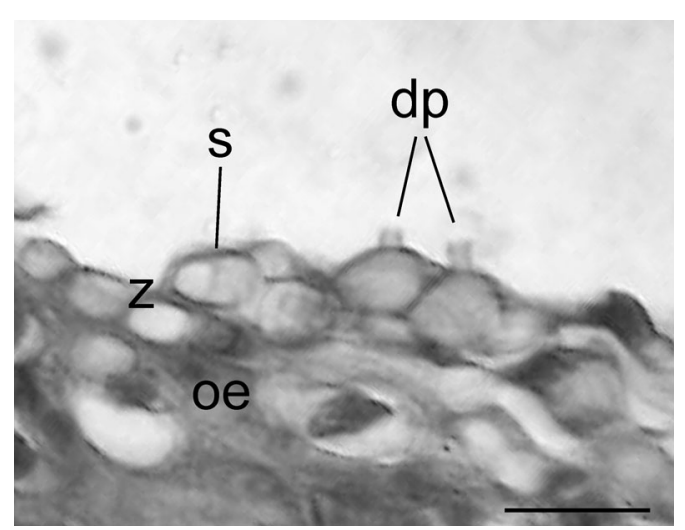

Fig. 1. Section of the oral epithelium (oe) in a Hypsiboas pulchellus tadpole. Empty zoosporangia (z) of Batrachochytrium dendrobatidis are evident; note the septum (s) and discharge papillae (dp). Scale bar $=20 \mu \mathrm{m}$

aspect made them indistinguishable from non-infected tadpoles, and no other concurrent diseases or external abnormalities were observed. The diagnosis was based on the observation of various developmental stages of Batrachochytrium dendrobatidis, mainly mature zoosporangia with zoospores and empty zoosporangia (which were the most common stage), sometimes exhibiting discharge papillae and septae (Fig. 1).

\section{DISCUSSION}

This is the first report of amphibian chytridiomycosis in wild amphibians from Uruguay, and also for the species Hypsiboas pulchellus, Odontophrynus maisuma, Physalaemus henselii and Scinax squalirostris. Batrachochytrium dendrobatidis was detected in tadpoles

Table 1. Details of specimens examined in the present study. ZVCB: Batrachians Collection of the Vertebrate Zoology Department, Faculty of Sciences, Montevideo, Uruguay. m.a.s.l.: meters above sea level; -: no voucher specimen deposited

\begin{tabular}{|c|c|c|c|c|c|c|}
\hline Species & $\mathrm{n}$ & Locality & Lat./Long. & $\begin{array}{l}\text { Altitude } \\
\text { (m a.s.l.) }\end{array}$ & $\begin{array}{l}\text { Collection } \\
\text { date }\end{array}$ & $\begin{array}{c}\text { ZVCB } \\
\text { voucher no. }\end{array}$ \\
\hline Hypsiboas pulchellus & 4 & $\begin{array}{l}\text { Road from La Paloma to } \\
\text { Laguna de Rocha, Rocha }\end{array}$ & $34^{\circ} 38^{\prime} \mathrm{S}, 54^{\circ} 12^{\prime} \mathrm{W}$ & 54 & 7 Aug 2006 & 16143 \\
\hline H. pulchellus & 2 & Delta del Tigre, San José & $34^{\circ} 46^{\prime} \mathrm{S}, 56^{\circ} 21^{\prime} \mathrm{W}$ & 5 & 2 Sep 2005 & 16144 \\
\hline $\begin{array}{l}\text { Melanophryniscus } \\
\text { montevidensis }\end{array}$ & 3 & Laguna de Rocha, Rocha & $34^{\circ} 39^{\prime} \mathrm{S}, 54^{\circ} 13^{\prime} \mathrm{W}$ & 0 & 10 Mar 2007 & - \\
\hline M. sanmartini & 2 & Sierra de las Ánimas, Maldonado & $34^{\circ} 44^{\prime} \mathrm{S}, 55^{\circ} 19^{\prime} \mathrm{W}$ & 450 & 15 Aug 2004 & 16141 \\
\hline Odontophrynus maisuma & 4 & Laguna de Rocha, Rocha & $34^{\circ} 39^{\prime} \mathrm{S}, 54^{\circ} 13^{\prime} \mathrm{W}$ & 0 & 7 Aug 2006 & 16142 \\
\hline Physalaemus biligonigerus & 1 & $\begin{array}{l}\text { Quebrada de los Cuervos, } \\
\text { Treinta y Tres }\end{array}$ & $32^{\circ} 57^{\prime} \mathrm{S}, 54^{\circ} 27^{\prime} \mathrm{W}$ & 185 & 4 Mar 2007 & 15192 \\
\hline P. henselii & 5 & Pueblo Madera, Rivera & $30^{\circ} 58^{\prime} \mathrm{S}, 55^{\circ} 34^{\prime} \mathrm{W}$ & 250 & 9 Oct 2001 & 16146 \\
\hline P. henselii & 3 & Barra de Valizas, Rocha & $34^{\circ} 20^{\prime} \mathrm{S}, 53^{\circ} 48^{\prime} \mathrm{W}$ & 2 & 10 Mar 2007 & 16149 \\
\hline Scinax squalirostris & 3 & Laguna de Rocha, Rocha & $34^{\circ} 39^{\prime} \mathrm{S}, 54^{\circ} 13^{\prime} \mathrm{W}$ & 0 & 7 Aug 2006 & 16145 \\
\hline
\end{tabular}




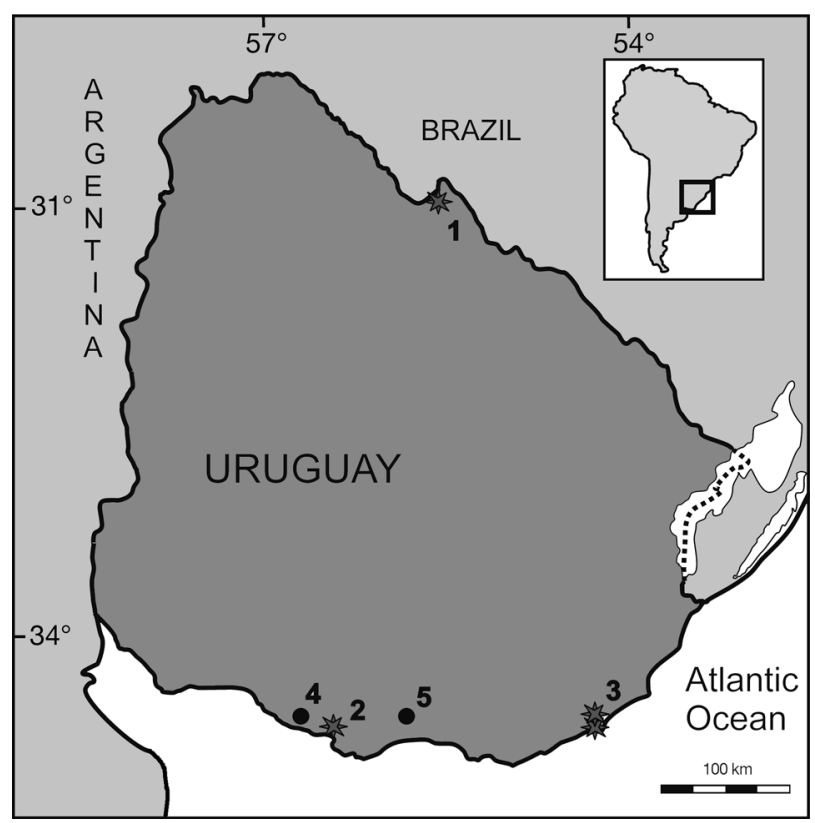

Fig. 2. Geographic distribution of Batrachochytrium dendrobatidis in Uruguay. (*) New records in this study: (1) Pueblo Madera, (2) Delta del Tigre, (3) Road to Laguna de Rocha and Laguna de Rocha. (•) Previous reports in farmed bullfrogs Lithobates catesbeianus: (4) Libertad (Mazzoni et al. 2003), (5) Empalme Olmos (Garner et al. 2006)

collected during austral winter and early spring, from August to October. Tadpoles of O. maisuma and $S$. squalirostris positive for chytridiomycosis were collected in the same pond where tadpoles of Melanophryniscus montevidensis were apparently free of infection in late summer (March). This may be due to the small sample of M. montevidensis we studied or to the sensitivity of the histological diagnosis, but could also be explained by specific differential susceptibility of tadpoles (Blaustein et al. 2005) and/or seasonality (Kriger \& Hero 2007). Mouthpart deformities observed in infected tadpoles are similar to those reported for amphibian chytridiomycosis elsewhere (Knapp \& Morgan 2006). Mouthpart deformities previously reported in tadpoles of $P$. henselii (Kolenc et al. 2006) were due to chytrid infection, as confirmed in the present study.

Most reports about chytrid-driven declines in South America conclude that amphibian populations at high elevations are more threatened than those inhabiting lowlands (Berger et al. 1998, La Marca et al. 2005, Barrionuevo \& Mangione 2006, Carnaval et al. 2006). However, reports of infection from coastal Uruguay (present study) and also from lowlands in Argentina (Herrera et al. 2005) indicate a wide altitudinal distribution of Batrachochytrium dendrobatidis in the region (see Table 1, Fig. 2). The presence of chytrid fungus in the population of Physalaemus henselii from northern
Uruguay is noteworthy as this species has apparently declined over much of its range in this country ( $F$. Kolenc \& C. Borteiro unpubl. data). In addition, the positive infection of $O$. maisuma is of special concern as this species has a narrow geographic distribution (Rosset 2008), mainly restricted to coastal habitats which are subject to disturbance due to rapid urbanization. During our surveys, adults of infected species studied herein were common at those sites where we detected $B$. dendrobatidis and dead adult amphibians were not found at any locality (F. Kolenc \& C. Borteiro pers. obs.). As opposed to adult amphibians, the pathogenic effects of $B$. dendrobatidis on amphibian larval communities and in turn on their entire ecosystems are still poorly understood (Parris \& Baud 2004, Ranvestel et al. 2004). We do not know the extent to which chytridiomycosis has impacted Uruguayan native amphibians, especially in coastal areas where amphibian declines caused by factors other than urbanization and habitat loss were recently reported (Kolenc et al. 2009).

Acknowledgements. We are grateful to M. Tedros, J. C. Borteiro, M. Pallas, G. Duarte and J. Valbuena for their hospitality and aid in surveys, P. Symonds for her suggestions, S. Ron, D. Martí and D. Baldo shared bibliography, and G. Duarte helped with image processing.

\section{LITERATURE CITED}

Barrionuevo S, Mangione S (2006) Chytridiomycosis in two species of Telmatobius (Anura: Leptodactylidae) from Argentina. Dis Aquat Org 73:171-174

Berger L, Speare R, Daszak P, Green DE and others (1998) Chytridiomycosis causes amphibian mortality associated with population declines in the rain forests of Australia and Central America. Proc Natl Acad Sci USA 95: 9031-9036

Berger L, Speare R, Kent A (1999) Diagnosis of chytridiomycosis in amphibians by histologic examination. Zoos Print J 15:184-190

Blaustein AR, Romansic JM, Scheessele EA, Han BA, Pessier AP, Longcore JE (2005) Interspecific variation in susceptibillity of frog tadpoles of the pathogenic fungus Batrachochytrium dendrobatidis. Conserv Biol 19:1460-1468

Carnaval ACOQ, Puschendorf R, Peixoto OL, Verdade VK, Trefaut Rodrigues M (2006) Amphibian chytrid fungus broadly distributed in the Brazilian Atlantic Rain Forest. EcoHealth 3:41-48

Daszak P, Berger L, Cunningham AA, Hyatt AD, Green DE, Speare R (1999) Emerging infectious diseases and amphibian population declines. Emerg Infect Dis 5: 735-748

> Daszak P, Cunningham AA, Hyatt AD (2003) Infectious disease and amphibian population decline. Divers Distrib 9: $141-150$

Daszak P, Lips K, Alford R, Carey C and others (2007) Infectious diseases. In: Gascon C, Collins JP, Moore RD, Church DR, McKay JE, Mendelson JR III (eds) Amphibian Conservation Action Plan. IUCN/SSC, Gland, p 21-25

Garner TWJ, Perkins MW, Govindarajulu P, Seglie D, Walker 
S, Cunningham AA, Fisher MC (2006) The emerging amphibian pathogen Batrachochytrium dendrobatidis globally infects introduced populations of North American bullfrog, Rana catesbeiana. Biol Lett 2:455-459

Herrera RA, Steciow MM, Natale GS (2005) Chytrid fungus parasitizing the wild amphibian Leptodactylus ocellatus (Anura: Leptodactylidae) in Argentina. Dis Aquat Org 64: 247-252

Knapp RA, Morgan JAT (2006) Tadpole mouthpart depigmentation as an accurate indicator of chytridiomycosis, an emerging disease of amphibians. Copeia 2006:188-197

Kolenc F, Borteiro C, Tedros M, Núñez D, Maneyro R (2006) The tadpole of Physalaemus henselii (Peters) (Anura: Leiuperidae). Zootaxa 136:41-50

Kolenc F, Borteiro C, Baldo D, Ferraro D, Prigioni C (2009) The tadpoles and advertisement calls of Pleurodema bibroni Tschudi and Pleurodema kriegi (Müller), with notes on their geographic distribution and conservation status (Amphibia, Anura, Leiuperidae). Zootaxa 1969:1-35

Kriger KM, Hero JM (2007) Large-scale seasonal variation in the prevalence and severity of chytridiomycosis. J Zool (Lond) 271:352-359

La Marca E, Lips KR, Lötters S, Puschendorf R and others (2005) Catastrophic population declines and extinctions in neotropical harlequin frogs (Bufonidae: Atelopus). Biotropica 37:190-201

Lips KR, Green DR, Pappendick R (2003) Chytridiomycosis in wild frogs from southern Costa Rica. J Herpetol 37: 215-218

Lips KR, Brem F, Brenes R, Reeve JD and others (2006) Emerging infectious disease and the loss of biodiversity in a Neotropical amphibian community. Proc Natl Acad Sci USA 103:3165-3170

Editorial responsibility: David Marcogliese, Montreal, Quebec, Canada
Mazzoni R, Cunningham AA, Daszak P, Apolo A, Perdomo E, Speranza G (2003) Emerging pathogen of wild amphibians in frogs (Rana catesbeiana) farmed for international trade. Emerg Infect Dis 9:995-998

Parris MJ, Baud DR (2004) Interactive effect of a heavy metal and chytridiomycosis on Gray tree Frog larvae (Hyla crysoscelis). Copeia 2004:344-350

Pounds JA, Bustamante MR, Coloma LA, Consuegra JA and others (2006) Widespread amphibian extinctions from epidemic disease driven by global warming. Nature 439: 161-167

Ranvestel AW, Lips KR, Pringle CM, Whiles MR, Bixby RJ (2004) Neotropical tadpoles influence stream benthos: evidence for the ecological consequences of decline in amphibian populations. Freshw Biol 49:274-285

Ron S (2005) Predicting the distribution of the amphibian pathogen Batrachochytrium dendrobatidis in the New World. Biotropica 37:209-221

Rosset SD (2008) New species of Odontophrynus Reinhardt and Lütken 1862 (Anura: Neobatrachia) from Brazil and Uruguay. J Herpetol 42:134-144

> Stuart SN, Chanson JS, Cox NA, Young BE, Rodrigues ASL, Fischman DL, Waller RW (2004) Status and trends of amphibian declines and extinctions worldwide. Science 306:1783-1786

Symonds EP, Hines HB, Bird PS, Morton JM, Mills PC (2007) Surveillance for Batrachochytrium dendrobatidis using Myxophyes (Anura: Myobatrachidae) larvae. J Wildl Dis 43:48-60

Toledo LF, Britto FB, Araújo OGS, Liasson LMO, Haddad CFB (2006) The occurrence of Batracochytrium dendrobatidis in Brazil and the inclusion of 17 new cases of infection. S Am J Herpetol 1:185-191

Submitted: June 12, 2008; Accepted: January 14, 2009

Proofs received from author(s): March 30, 2009 